\title{
Isotopic of nitrogen and chemical analysis of deferred grazing marandu palisadegrass fertilized with urea and poultry litter
}

\author{
Análise isotópica de nitrogênio e química do capim-marandu \\ adubado com ureia e cama de frango e diferido
}

\author{
Vânia Luzia Fournou de Lima ${ }^{1 *}$; Carlos Ducatti²; Paulo Roberto de Lima Meirelles ${ }^{3}$; \\ Luciane do Carmo Seraphim ${ }^{1}$; Marco Aurélio Factori ${ }^{4}$; André Mendes Jorge ${ }^{3}$; \\ Roberto Lyra Villas Bôas ${ }^{5}$; Marina Gabriela Berchiol da Silva ${ }^{3}$
}

\begin{abstract}
This study aimed to evaluate and quantify the methodology of stable isotopes, ${ }^{15} \mathrm{~N}$ values for the organic fertilizer (chicken manure) and inorganic (urea). In addition to evaluating the incorporation rate, chemical half-life and analysis thereof, for possible traceability through the pasture fertilized with different sources of $\mathrm{N}$. The technique of employment with use of tracer stable isotope ${ }^{15} \mathrm{~N}$ possible to estimate the changes in the $\mathrm{N}$ soil, even in the face of the various changes that take place concurrently. The methodology determines the path of both $\mathrm{N}$ isotopes $\left({ }^{15} \mathrm{~N}\right.$ and $\left.{ }^{14} \mathrm{~N}\right)$, providing information about the system and estimating $\mathrm{N}$ transformation rates The experimental work was conducted at the Faculty of Veterinary Medicine and Animal Science, UNESP Botucatu. An area of $576 \mathrm{~m}^{2}$ was used for the parcels, which were divided between the 3 treatments with 4 repetitions each: T1 - control treatment without fertilization; $\mathrm{T} 2$ - fertilization with urea and T3 - organic fertilizer with poultry litter. The grass was cut every 15 days, three months after fertilization, for a total of four periods of grazing exclusion. Experimental samples were analyzed for the isotopic nitrogen and crude protein, neutral detergent fiber, acid detergent fiber, cellulose, hemicellulose and lignin composition. Degradation of poultry litter, the sand bag method was analyzed by linear regression. $\delta^{15} \mathrm{~N}$ forage, fodder percentage of nitrogen, percentage of total nitrogen sheet, $\delta^{15} \mathrm{~N}$ on the sheet, and $\delta^{15} \mathrm{~N}$ at the helm were different between treatments. To this end collection, difference was observed for $\%$ Total Nitrogen, $\%$ Total $\mathrm{N}$ in sheet, $\%$ Total $\mathrm{N}$ in the trunk and $\%$ Total $\mathrm{N}$ at the helm. The crude protein analysis revealed significant differences between treatments, while the crude protein and lignin differ according to time after fertilization. The technique of $\mathrm{N}$ stable isotope effectively distinguish the composition of organic and inorganic fertilizers in deferred grazing pastures of Urochloa brizantha $\mathrm{cv}$. Marandu. Forage quality was not influenced by the source of N.
\end{abstract}

Key words: Poultry litter. Isotopes. Urea. Pasture exclusion.

\section{Resumo}

Objetivou-se avaliar e quantificar, pela metodologia dos isótopos estáveis, os valores de ${ }^{15} \mathrm{~N}$ para o adubo orgânico (cama de frango) e inorgânico (ureia). Além de avaliar a taxa de incorporação, meia vida e analises

\footnotetext{
${ }^{1}$ Discentes do Curso de Doutorado em Zootecnia, Universidade Estadual Paulista, UNESP, Botucatu, SP, Brasil. E-mail: fournou. vania@gmail.com; lucianeseraphim@yahoo.com.br

2 Prof. Dr., IBB/UNESP, Botucatu, SP, Brasil. E-mail: ducatti@ibb.unesp.br (In Memorian)

3 Profs. Drs., FMVZ/UNESP, Botucatu, SP, Brasil. E-mail: paulom@fmvz.unesp.br; andrejorge1@gmail.com; gabiberchiol@ hotmail.com

${ }^{4}$ Dr. em Zootecnia, UNESP, Botucatu, SP, Brasil. E-mail: mafactori@hotmail.com

5 Prof. Dr., FCA/UNESP, Botucatu, SP, Brasil. E-mail: rlvboas@fca.unesp.br

* Author for correspondence
} 
química dos mesmos, para uma possível rastreabilidade por meio da pastagem adubada com diferentes fontes de N. O emprego da técnica com utilização do traçador do isótopo estável ${ }^{15} \mathrm{~N}$ permitem estimar as modificações do $\mathrm{N}$ no solo, mesmo diante das variadas transformações que acontecem concomitantemente. A metodologia determina o caminho de ambos os isótopos de $\mathrm{N}\left({ }^{15} \mathrm{~N} \mathrm{e}^{14} \mathrm{~N}\right)$, fornecendo informações acerca do sistema e estimando as taxas de transformação do N. O presente estudo teve por objetivo determinar o valor isotópico do ${ }^{15} \mathrm{~N}$ e composição química em condições naturais do capim-marandu (Urochloa brizantha cv. Marandu), sob o diferimento em função da adubação utilizada, em quatro cortes após a vedação. $\mathrm{O}$ trabalho foi desenvolvido na Faculdade de Medicina e Veterinária e Zootecnia da UNESP de Botucatu. A área, $576 \mathrm{~m}^{2}$, utilizada para as parcelas foi dividida em 3 tratamentos com 4 repetições cada, segundo os tratamentos: T1 - tratamento testemunho sem adubação; T2 - adubação com ureia e T3 - adubação orgânica com cama de frango. Após três meses, o capim foi cortado a cada 15 dias, totalizando quatro períodos de vedação. As amostras colhidas no experimento foram analisadas em relação ao sinal isotópico do nitrogênio e composição química de proteína bruta, fibra em detergente neutro, fibra em detergente ácido, celulose, hemicelulose e lignina. A degradação do adubo cama de frango, pelo método do litter bag, foi analisada por meio de regressão. Existe diferença para $\delta^{15} \mathrm{~N}$ na forragem em relação aos tratamentos utilizados, assim como para porcentagem de Nitrogênio na forragem, porcentagem de Nitrogênio Total na Folha, $\delta^{15} \mathrm{~N}$ na folha, $\delta^{15} \mathrm{~N}$ no perfilho. Para o efeito coleta houve diferença para $\%$ Nitrogênio Total, $\% \mathrm{~N}$ total na folha, $\% \mathrm{~N}$ total no colmo e $\% \mathrm{~N}$ total no perfilho. Para análise de Proteína Bruta, houve diferença entre tratamentos, porém quando analisadas as coletas, foram encontradas diferença na proteína bruta e na lignina. A técnica dos isótopos estáveis do $\mathrm{N}$ foi eficaz na discriminação entre a adubação inorgânica e orgânica na pastagem de Urochloa brizantha cv. Marandu diferida e para a composição bromatológica, a fonte de $\mathrm{N}$ não influenciou a qualidade da forragem.

Palavras-chave: Cama de frango. Isótopos. Ureia. Vedação de pastagem.

\section{Introduction}

An important feature of Brazilian livestock is the use of pasture as their main food source (FERRAZ; FELÍCIO, 2010), making Brazil's meat production costs one of the lowest in the world (CARVALHO et al., 2009; DEBLITZ, 2012; FERRAZ; FELÍCIO, 2010). This livestock raising method is possible due to the climate characteristics and territorial extension of the country - according to estimates from the 2006 Brazilian Agriculture Census, Brazil has a total area of 172.3 million hectares of natural and planted pastures (IBGE, 2007). Increasing pasture productivity helps further decreasing costs, and nitrogen fertilization is among the most important factors determining forage production per area (CORSI, 1986; ANDRADE; VALENTIN, 2004; BATISTA; MONTEIRO, 2006). Poultry litter, a waste product of poultry farming, is rich in nitrogen, phosphate and potassium, and thus has been used both as an organic fertilizer (NYAKATAWA et al., 2001; PREUSCH et al., 2002; FRIEND et al., 2006; MCGRATH et al., 2009), as well as a component of ruminant feed, reducing farming costs and contributing to solve waste disposal problems. However, the risk of Bovine Spongiform Encephalopathy (BSE), led the Ministry of Agriculture, Livestock and Supply (MAPA) to forbid the use of poultry litter in ruminant feed in Brazil from 2004 (MAPA, 2004; MAPA, 2009a). Pasture fertilization is, therefore, the only possibility open to milk and meat producers to use poultry litter to reduce their production costs, at the same time helping poultry farmers to reduce their waste disposal costs. However, MAPA also limits the use of poultry litter as a fertilizer in pastures to an interval of 40 days after fertilization for the entry of ruminants (MAPA, 2009b).

Deferred grazing, the practice of resting part of the pasture area, is used in Brazil before the end of the rainy season, in order to accumulate and transfer fodder to be consumed during the dry season. Nitrogen fertilization allows flexibility in the pasture deferment period, since nitrogen increases grass growth rate and consequently the amount of forage produced per unit time, making it possible to obtain similar forage production with different periods of 
deferment by using different nitrogen rate applied to the deferral. However, nitrogen fertilization performed in late summer or fall, when soil moisture begins to decrease and when deferral is usually started, can result in nitrogen losses by volatilization, depending on the nitrogen source used (MARTHA JÚNIOR et al., 2004) - according to Menezes et al. (2004), organic materials gradually release macro and micronutrients to the soil solution, depending on the degree of mineralization of the compound, on the raw material that gave rise to the compound and on the amount applied. Nitrogen losses may reduce or eliminate the expected result of fertilization. This means that the efficient use of poultry litter in pasture fertilization during deferral requires an appropriate understanding of the decomposition and release of nutrients from poultry litter to the ground. So far, few studies have compared organic and mineral fertilization at similar rates (PAUL; CLARK, 1996).

This study aimed to fill this gap, by generating nitrogen isotopic patterns in pastures using different nitrogen sources, at different cutting times, as a way of characterizing management used in pastures, and of eliminating the possibility of a false positive if the isotopic value is similar to the value of animals receiving sources of protein origin, prohibited in our country. To do that, we determined the isotopic value of ${ }^{15} \mathrm{~N}$ for forage production and chemical composition of marandugrass (Brachiaria brizantha (Hochst. ex A. Rich.) RD Webster [syn. Urochloa brizantha (A. Rich.) Stapf]) in natural conditions, upon mineral or organic fertilization after the deferment period.

Stable isotopes have been used for decades in studies concerning ruminant animals. This is because isotopic values are calculated based on assimilated food and not just on food intake. Therefore, this technique allows obtaining information on recently consumed diets or even on diets that were provided in early periods of the animal's life (HOBSON; CLARK, 1992).

According to Schaeffer and Caugant (1998), the concept of traceability involves restoring the food product history. Therefore, it may be useful to establish: the exact livestock or vegetable origin of production, with the various factors incorporating its development; the history of processes applied to the product; the distribution and location of the finished product. All identifiers and information exchanges have to be standardized without weaknesses to ensure strength and reliability. The adoption of innovative or less conventional technologies (assessed by research conducted in livestock production systems in Brazil) is slow and has a low impact, partly due to the profile of Brazilian farmers.

The deferral of grazing is the rest of part of the area of the property pastures, before the end of the rainy season, in order to accumulate and transfer fodder to be consumed during the dry season. Nitrogen fertilization can also allow greater flexibility in the pasture deferment period, since the nitrogen increases the grass growth rate and consequently the amount of forage produced per unit time. Thus, it is possible to obtain similar forage production, even adopting different periods of deferment. Differences in nitrogen rate applied to the deferral would be responsible for this similar forage production.

However, nitrogen fertilization, when performed in late summer or fall when soil moisture begins to reduce, can result in nitrogen losses by volatilization, depending on the nitrogen source used (MARTHA JÚNIOR et al., 2004). And it is in late summer and / or early fall that usually takes place the beginning of the deferred pastures. If these losses occur, the expected result of fertilization can be reduced, or even not occur, resulting in low efficiency and apparent recovery of nitrogen applied and lower forage production. Little is known about the decomposition and release of nutrients from poultry litter to the ground (PAUL; CLARK, 1996). Few studies have compared organic and mineral fertilization at similar rates.

According to Menezes et al. (2004), the organic material gradually releases macro and micronutrients 
to the soil solution. Such release occurs as the organic material is being mineralized. The amount released depends on the degree of mineralization of the compound, the raw material that gave rise to the compound and the amount applied. It is hoped that this project generate nitrogen isotopic pattern in pastures with different fertilizer nitrogen at different cutting times as a way of characterizing managements used in pastures, and eliminate the possibility of a false positive if the isotopic value is similar to the value of animals receiving sources of protein origin, prohibited in our country.

\section{Materials and Methods}

The study was conducted at the Universidade Estadual Paulista - UNESP School of Veterinary
Medicine and Animal Science, in Botucatu. The experimental soil classification was dystrophic red latosol, and the climate in the region is high altitude tropical, with a dry winter and hot and rainy summer (LOMBARDI NETO; DRUGOWICH, 1994), with $1300 \mathrm{~mm}$ average rainfall. The experimental area was sown in February 2004 with marandu grass, and kept under continuous grazing by buffaloes. The area was limed, but did not receive any kind of fertilizer in the three years prior to the start of the experiment, to make it comparable to most Brazilian pastures. Macronutrients were measured from soil samples and from poultry litter bags (see below) collected from the 0-0.20 m layer of the field prior to the experiment (Table 1). Minimum and maximum temperatures were $12^{\circ} \mathrm{C}$ and $22^{\circ} \mathrm{C}$, respectively, from April to August (deferment period) (Figure 1).

Table 1. Analyses of the soil and poultry litter used in the experiment.

\begin{tabular}{|c|c|c|c|c|c|c|c|c|c|c|c|}
\hline \multicolumn{12}{|c|}{ Soil Analysis } \\
\hline $\mathrm{pH}$ & $\mathrm{OM}$ & $\mathrm{P}_{\text {resin }}$ & $\mathrm{Al}^{3+}$ & $\mathrm{H}^{+} \mathrm{Al}$ & $\mathrm{K}$ & $\mathrm{Ca}$ & $\mathrm{Mg}$ & SB & CTC & $\mathrm{V} \%$ & $\mathrm{~S}$ \\
\hline $\mathrm{CaCl}_{2}$ & $g / L$ & $\mathrm{mg} / \mathrm{L}$ & \multicolumn{8}{|c|}{ 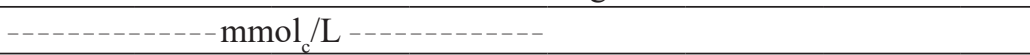 } & $\mathrm{mg} / \mathrm{L}$ \\
\hline 5.2 & 10 & 4 & $-{ }_{--}$ & 13 & 0.5 & 6 & 5 & 12 & 25 & 47 & --- \\
\hline \multicolumn{12}{|c|}{ Poultry litter analysis (\%) } \\
\hline $\mathrm{N}$ & $\mathrm{P}_{2} \mathrm{O}_{5}$ & $\mathrm{~K}_{2} \mathrm{O}$ & $\mathrm{Ca}$ & $\mathrm{Mg}$ & $\mathrm{S}$ & $\mathrm{DM}$ & OM & & & & \\
\hline 4.27 & 2.32 & 2.26 & 2.47 & 0.5 & 0.59 & 87 & 61 & & & & \\
\hline
\end{tabular}

Figure 1. Climate data (rainfall, temperature: minimum, medium, maximum) for the trial period.

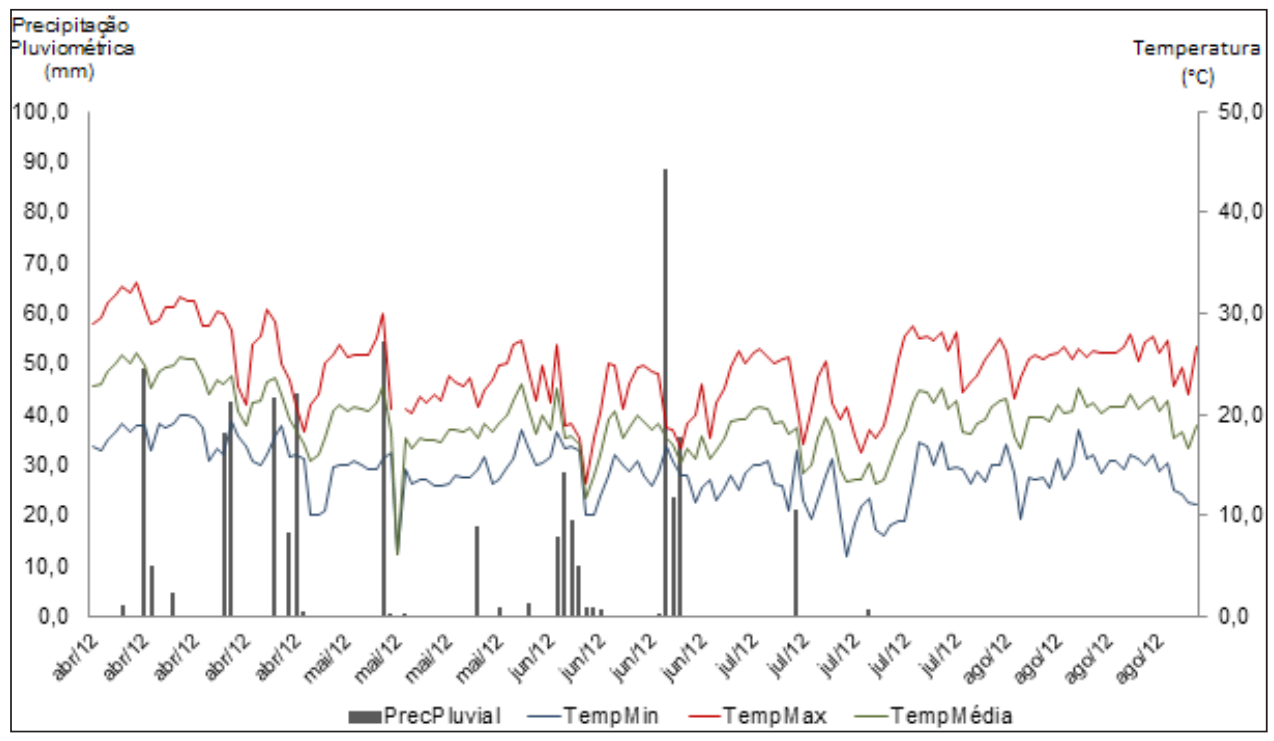


The experimental area measured $576 \mathrm{~m}^{2}$, divided into 3 treatments: T1 - control treatment, without fertilization; T2 - fertilization with urea to $70 \mathrm{~kg} \cdot \mathrm{ha}^{-1}$ nitrogen $(\mathrm{N})$, T3 - organic fertilization with 4,000 $\mathrm{kg} \cdot \mathrm{ha}^{-1}$ poultry litter, corrected to $87 \%$ of dry matter (DM). Poultry litter was obtained from a poultry farm with four chicken production cycles (three sets). Fertilizers were broadcast applied manually, only once (ARRUDA, 2012), on April 1 $1^{\text {st }}$ (Day 0 ), after cutting the sward to an uniform height, followed by 90 days of deferral (exclusion of cattle from pasture). Sample collections (cuttings) of the forage were performed in day 0 and every 15 days after 90 days of deferral (on July $1^{\text {st }}$ and $15^{\text {th }}$, August $1^{\text {st }}$ and $15^{\text {th }}$, each with four samples per plot, spaced two meters. Grass samples were obtained from a $0.5 \mathrm{~m} \times 0.5 \mathrm{~m}$ square $\left(0.25 \mathrm{~m}^{2}\right)$, cut 5 $\mathrm{cm}$ above the soil. A sub-sample was removed from the cut forage, dried in a $65^{\circ} \mathrm{C}$ forced-air furnace to constant mass, ground in a Wiley mill with 1 $\mathrm{mm}$ sieves, and returned to a furnace at $105^{\circ} \mathrm{C}$ for 12 hours to determine dry matter content (AOAC, 1995). Another sub sample was used to calculate crude protein (CP), according to the AOAC (1995) technique, and neutral detergent fiber (NDF), acid detergent fiber (ADF) and lignin (LIG), according to the techniques described by Van Soest et al. (1991), adapted by Mertens (2002). These analyses were performed at the Bromatology Laboratory at the Universidade Estadual Paulista - UNESP School of Veterinary Medicine and Animal Science, in Botucatu.

For each treatment and sampling time, six tillers were collected to determine the isotopic nitrogen signal, of which three were separated into leaf and stem+sheath, while the others were analyzed whole. For the isotopic analysis, the samples were placed into tin capsules and weighted (2000-3000 $\mu \mathrm{g})$ in an analytical scale accurate to six decimal places. To measure the isotopic composition of the samples with natural abundance, we used isotope-ratio mass spectrometers coupled to elemental analyzers (Delta S - Finnigan MAT, Bremen, Germany, coupled to EA 1108 - CHN - Fisons Instruments, Rodano, Italy and Delta V Advantage Isotope Ratio MS, Thermo Scientific, Germany, coupled to Flash 2000 Organic Elemental Analyzer EA for IRMS) in which the sample was quantitatively burned, in the presence of oxygen $\left(\mathrm{O}_{2}\right)$ and copper oxide $(\mathrm{CuO})$, to obtain $\mathrm{N}_{2}$. The formed gases were separated in a gas chromatography column and analyzed in the mass spectrometer. The results, expressed in $\delta$ notation, compared to the $\delta{ }^{15} \mathrm{~N}$ atmospheric air standard, with an analysis error in the order of $0.2 \%$, were calculated from equation 1 :

$\delta_{\text {(sample, standard) }}=\left[\left(\mathrm{R}_{\text {sample }} / \mathrm{R}_{\text {standard }}\right)-1\right]$

Wherein:

$\delta=$ sample enrichment relative to the standard. Dimensionless.

$\mathrm{R}=$ isotope ratio between the sample and the dimensionless standard.

The decomposition and release of nutrients from poultry litter were determined by the method of "litter bags", adapted from Bocock and Gilbert (1975). This technique uses bags made with nylon screens with a $1 \mathrm{~mm}$ mesh, filled with poultry litter and placed into the soil in the experimental areas. The dimensions of the pouches were $0.2 \mathrm{~m} \times 0.2$ $\mathrm{m}$, covering an area of $0.04 \mathrm{~m}^{2}$, and were filled with $100 \mathrm{~g}$ of poultry litter according to the ratio of the mass quantity per hectare area thereof and the bag. To fill the bags, poultry litter was dried in a forced-air furnace at $60^{\circ} \mathrm{C}$ for 24 hours. For each forage collection, one bag was recovered from the ground to assess the incorporation of fertilizer to the soil, weighed and the chemical composition of its contents analyzed. The exponential function of the Minitab ${ }^{\circledR}$ software, version 16 (MINITAB, 2010) was used to measure nitrogen isotope turnover in a period of time (isotope dilution), equation (2):

$\delta^{15} \mathrm{~N}(\mathrm{t})=\delta^{15} \mathrm{~N}(\mathrm{f})+\left[\delta^{15} \mathrm{~N}(\mathrm{i})-\delta^{15} \mathrm{~N}(\mathrm{f})\right] \mathrm{e}^{-\mathrm{kt}}$

Wherein:

$\delta^{15} \mathrm{~N}(\mathrm{t})=$ isotopic enrichment of the tissue at any 
time $(\mathrm{t})$. Dimensionless.

$\delta^{15} \mathrm{~N}(\mathrm{f})=$ isotopic enrichment of the tissue in the balance level or final condition. Dimensionless.

$\delta^{15} \mathrm{~N}(\mathrm{i})=$ isotopic enrichment of the fabric in the initial state. Dimensionless.

$\mathrm{k}=$ exchange constant (turnover). Expressed in days $^{-1}$

$\mathrm{t}=$ time (in days) since the change of diet (fertilization).

Constant $\mathrm{k}$ includes the nitrogen metabolic turnover process that contributes to nitrogen isotopic dilution.

Equation (3) was used to determine the half-life of the $50 \%$ condition (fraction exchanged atoms):

$\mathrm{T}=\ln 2 / \mathrm{k}$

Wherein:

$\mathrm{t}=$ nitrogen exchange time

$\mathrm{k}=$ exchange constant (turnover) in time $\mathrm{e}^{-1}$ units

Equation (4) was used to determine the time for exchange of $99 \%$ of the ${ }^{15} \mathrm{~N}$ atoms

$\mathrm{t}=(-1 / \mathrm{k}) \ln (1-\mathrm{F})$

Wherein:

$\mathrm{t}=$ nitrogen exchange time

$\mathrm{k}=$ exchange constant (turnover) in time $\mathrm{e}^{-1}$ units

$\mathrm{F}=$ fraction of exchanged atoms

The half-life ( $\mathrm{t}=\mathrm{T})$ was the time for the exchange of $50 \%$ of ${ }^{15} \mathrm{~N}$ for each treatment $(\mathrm{F}=0.5)$.

The data on the rate of decomposition of poultry litter were evaluated by linear regression, using Origin Pro 8 software. Means were compared with the Tukey test at $5 \%$ probability using Minitab $\mathbb{R}$ software, version 16 (MINITAB, 2010).

\section{Results and Discussion}

Table 1 shows the results of the analysis of soil and poultry litter. Low soil contents of phosphate (4 $\mathrm{mg} / \mathrm{L})$ and potassium $(0.5 \mathrm{mmol} / \mathrm{L})$ were consistent with the Brazilian reference. Poultry litter contained $4.27 \%$ nitrogen $(\mathrm{N}), 2.32 \%$ phosphate $\left(\mathrm{P}_{2} \mathrm{O}_{5}\right)$ and 2.26 Potassium $\left(\mathrm{K}_{2} \mathrm{O}\right)$. N values were used to adjust the amount of poultry litter used in fertilization (ARRUDA, 2012).

Table 2 summarizes the forage nitrogen content $(\%),{ }^{15} \mathrm{~N}$ isotopic enrichment $\left(\delta^{15} \mathrm{~N}\right)$, and composition analysis for the forage and its parts. Total nitrogen content (\% Total Nitrogen) varied significantly among treatments, as did leaf nitrogen content (\%TNL), total $\delta^{15} \mathrm{~N}$, leaf $\delta^{15} \mathrm{~N}$ $\left(\delta^{15} \mathrm{~N}\right.$ leaf $)$ and tiller $\delta^{15} \mathrm{~N}\left(\delta^{15} \mathrm{~N}\right.$ tiller $)$. A collection effect was observed for $\%$ Total Nitrogen, $\% \mathrm{TNL}$, stem nitrogen content (\%TNS) and tiller nitrogen content (\%TNT), but not for $\delta^{15} \mathrm{~N}$ in either the whole plant or its parts. There were also differences in crude protein and cellulose contents among treatments and collections, and among collections lignin content.

While \% Total Nitrogen was similar for both fertilizers and significantly higher than for the unfertilized control, $\delta^{15} \mathrm{~N}$ was significantly different among all treatments, with the highest value for the poultry litter treatment and a negative value for the unfertilized control (Table 3). For all treatments a significant decrease in nitrogen content was observed between the second and the third sample collections (Table 3 ). 
Table 2. Estimated average, summary of the analysis of variance and minimum significant difference of nitrogen concentration in relation to fertilizers and collections.

\begin{tabular}{lcccc}
\hline \multirow{2}{*}{ Component } & Average & \multicolumn{3}{c}{ Effect } \\
\cline { 3 - 5 } \% Total Nitrogen & 1.28 & Treatment & Collection & Treatment x Collection \\
$\delta^{15} \mathrm{~N}$ & 0.80 & $*$ & $*$ & $*$ \\
$\% \mathrm{TNL}$ & 1.88 & $*$ & - & - \\
$\% \mathrm{TNS}$ & 1.55 & $*$ & $*$ & - \\
$\% \mathrm{TNT}$ & 0.91 & - & $*$ & - \\
$\delta^{15} \mathrm{~N}$ leaf & 0.87 & - & - & - \\
$\delta^{15} \mathrm{~N}$ stem & 1.02 & $*$ & - & - \\
$\delta^{15} \mathrm{~N}$ tillers & 1.36 & - & - & - \\
Productivity MS & & $*$ & $*$ & - \\
Crude protein & 9.09 & $*$ & $*$ & - \\
NDF & 71.30 & $*$ & - & - \\
ADF & 29.58 & - & - & $*$ \\
Cellulose & 22.95 & - & $*$ & - \\
Lignin & 29.89 & - & $*$ & - \\
\hline
\end{tabular}

TNL: Total Nitrogen leaf; TNS: Total Nitrogen stem; TNT: Total Nitrogen Tiller; NDF: Neutral Detergent Fiber; ADF: Acid Detergent Fiber; $\delta^{15} \mathrm{~N}$ leaf $:{ }^{15} \mathrm{~N}$ isotopic enrichment in the leaf; $\delta^{15} \mathrm{~N}$ stem $:{ }^{15} \mathrm{~N}$ isotopic enrichment in the stem ; $\delta^{15} \mathrm{~N}$ tiller $:{ }^{15} \mathrm{~N}$ isotopic enrichment in the tiller ;* indicates statistical differences between treatments, among collections, and for the interaction of treatment and collection $(\mathrm{P}<0.05)$.

Table 3. Means of percentage (\%) of Total Nitrogen and $\delta^{15} \mathrm{~N}$ in the forage for different treatments and each of the four forage sample collections.

\begin{tabular}{lcccc}
\hline \multirow{2}{*}{ Variable } & \multicolumn{3}{c}{ Treatments } \\
\cline { 2 - 5 } & Unfertilized & Urea & \multicolumn{2}{c}{ Poultry litter } \\
\hline \% Total Nitrogen & $1.11 \mathrm{~b}$ & $1.32 \mathrm{a}$ & $1.39 \mathrm{a}$ \\
$\delta^{15} \mathrm{~N}$ & $-0.78 \mathrm{c}$ & $0.88 \mathrm{~b}$ & $2.31 \mathrm{a}$ \\
\hline \multirow{2}{*}{ Variable } & \multicolumn{2}{c}{ Collection } & \\
\cline { 2 - 5 } & 1 & 2 & $1.04 \mathrm{~b}$ & $0.97 \mathrm{~b}$ \\
$\% \mathrm{~N}$ UC & $1.14 \mathrm{a}$ & $1.29 \mathrm{a}$ & $1.09 \mathrm{~b}$ & $1.11 \mathrm{~b}$ \\
$\% \mathrm{~N}$ Urea & $1.50 \mathrm{a}$ & $1.60 \mathrm{a}$ & $1.28 \mathrm{~b}$ & $1.15 \mathrm{~b}$ \\
\hline
\end{tabular}

$\% \mathrm{~N}$ UC: percentage of nitrogen in the unfertilized control pasture; $\% \mathrm{~N}$ Urea: percentage of nitrogen in the pasture fertilized with urea; \% N PL: percentage of nitrogen in the pasture fertilized with poultry litter; values with the same letter on rows are statistically similar ( $\mathrm{P}>0.05) ; 1,2,3,4$ : first, second, third and fourth forage sample collections.

While nitrogen content in leaves, stems and tillers were significantly lower for all sample collections compared with day 0 (start of the experiment), it did not vary among collections, except for stem nitrogen content, which was significantly lower in the third sample collection compared with the others (Table 4). 
Table 4. Leaf nitrogen content (\%TNL), stem nitrogen content (\%TNS) and tiller nitrogen content (\%TNT) in day 0 and in each of the forage sample collections.

\begin{tabular}{llllll}
\hline \multirow{2}{*}{ Variable } & \multicolumn{5}{c}{ Collection } \\
\cline { 2 - 6 } & Day 0 & 1 & 2 & 3 & 4 \\
\hline \%TNL & $3.04 \mathrm{a}$ & $1.81 \mathrm{~b}$ & $1.67 \mathrm{~b}$ & $1.43 \mathrm{~b}$ & $1.46 \mathrm{~b}$ \\
$\% \mathrm{TNS}$ & $2.40 \mathrm{a}$ & $1.50 \mathrm{ab}$ & $1.53 \mathrm{ab}$ & $0.88 \mathrm{~b}$ & $1.43 \mathrm{ab}$ \\
\%TNT & $1.63 \mathrm{a}$ & $0.81 \mathrm{~b}$ & $0.85 \mathrm{~b}$ & $0.79 \mathrm{~b}$ & $0.48 \mathrm{~b}$ \\
\hline
\end{tabular}

Values with the same letter on rows are not significantly different (P>0.05) * \%TNL: \% Nitrogen in the leaf; \%TNS: \% Nitrogen in the stem; \%TNT: \% Nitrogen in the tiller; 1,2,3,4: first, second, third and fourth forage sample collections; Day 0: first day of experiment, before fertilization and before deferral of grazing.

Table 5 shows that leaf nitrogen content (\%TNL) and leaf ${ }^{15} \mathrm{~N}$ isotopic enrichment $\left(\delta^{15} \mathrm{~N}\right.$ leaf $)$ both increased significantly from unfertilized control to urea to poultry litter. $\delta^{15} \mathrm{~N}$ tiller, however, was higher in poultry litter, but similar between unfertilized control and urea fertilization.

Crude protein content increased with fertilization, but there was no difference between urea and poultry litter, whereas ADF and NDF were similar for all conditions (Table 6). Crude protein was also higher in the first two collections, whereas lignin content was different for each collection; ADF and NDF did not vary among collection times (Table 6). This result is explained by the fact that the organic fertilizer is released slowly in the match against mineral fertilizer suffer the intervention of leaching and nitrification. And for that reason it is that their values were matched to the treatment without fertilization.

Table 5. Means of $\delta^{15} \mathrm{~N}$ (leaf and tiller), and leaf nitrogen content (\%TNL) by treatment.

\begin{tabular}{lccc}
\hline \multirow{2}{*}{ Variable } & \multicolumn{3}{c}{ Treatment } \\
\cline { 2 - 4 } & Unfertilized & Urea & Poultry litter \\
\hline$\delta^{15} \mathrm{~N}$ leaf & $-1.25 \mathrm{~b}$ & $0.38 \mathrm{ab}$ & $3.46 \mathrm{a}$ \\
$\delta^{15} \mathrm{~N}$ tiller & $-0.89 \mathrm{~b}$ & $1.06 \mathrm{~b}$ & $3.91 \mathrm{a}$ \\
$\% \mathrm{TNL}$ & $1.58 \mathrm{~b}$ & $1.90 \mathrm{ab}$ & $2.16 \mathrm{a}$ \\
\hline
\end{tabular}

Values with the same letter on rows are statistically similar $(\mathrm{P}>0.05) ; \delta^{15} \mathrm{~N}$ leaf $:{ }^{15} \mathrm{~N}$ isotopic enrichment in the leaf; $\delta^{15} \mathrm{~N}$ tiller $:{ }^{15} \mathrm{~N}$ isotopic enrichment in the tiller; \%NL: \% Nitrogen in the leaf

Table 6. Estimated average (\%) for crude protein and lignin used for treatments and collections.

\begin{tabular}{|c|c|c|c|c|}
\hline \multirow{2}{*}{ Variables } & \multicolumn{4}{|c|}{ Treatment } \\
\hline & Unfertilized & Urea & \multicolumn{2}{|c|}{ Poultry litter } \\
\hline Crude protein & $8.04 \mathrm{~b}$ & $9.44 \mathrm{a}$ & \multicolumn{2}{|c|}{$9.79 \mathrm{a}$} \\
\hline $\mathrm{NDF}$ & $70.76 \mathrm{a}$ & $70.86 a$ & \multicolumn{2}{|c|}{$72.28 \mathrm{a}$} \\
\hline $\mathrm{ADF}$ & $28.34 \mathrm{a}$ & $31.10 \mathrm{a}$ & \multicolumn{2}{|c|}{$29.48 \mathrm{a}$} \\
\hline \multirow{2}{*}{ Variables } & \multicolumn{4}{|c|}{ Collection } \\
\hline & 1 & 2 & 3 & 4 \\
\hline Crude protein & $9.90 \mathrm{a}$ & $10.55 \mathrm{a}$ & $7.99 \mathrm{~b}$ & $7.93 \mathrm{~b}$ \\
\hline Lignin & $27.90 \mathrm{~b}$ & $30.32 \mathrm{a}$ & $30.23 \mathrm{ab}$ & $31.11 \mathrm{a}$ \\
\hline NDF & $71.04 \mathrm{a}$ & $71.76 \mathrm{a}$ & $71.19 \mathrm{a}$ & $71.21 \mathrm{a}$ \\
\hline $\mathrm{ADF}$ & $29.00 \mathrm{a}$ & $31.30 \mathrm{a}$ & $29.31 \mathrm{a}$ & $28.71 \mathrm{a}$ \\
\hline
\end{tabular}

NDF: neutral detergent fiber; ADF: acid detergent fiber; values with the same letter on rows are statistically similar (P $>0.05)$; $1,2,3,4$ : first, second, third and fourth forage sample collections. 
An exponential model was used to demonstrate the behavior of the isotopic values along the experimental period (Figure 2). By day 40, the forage had already incorporated the isotopic signal of the fertilizer, staying in equilibrium until the end of the experiment. Table 7, the equations for determining the incorporation of $\delta^{15} \mathrm{~N}$ for poultry litter and urea are shown. Regarding the half-life there was a difference between treatments, observing higher values for the poultry litter.

Figure 2. Exponential model for the isotopic value within the trial period of the treatments evaluated in the pasture.

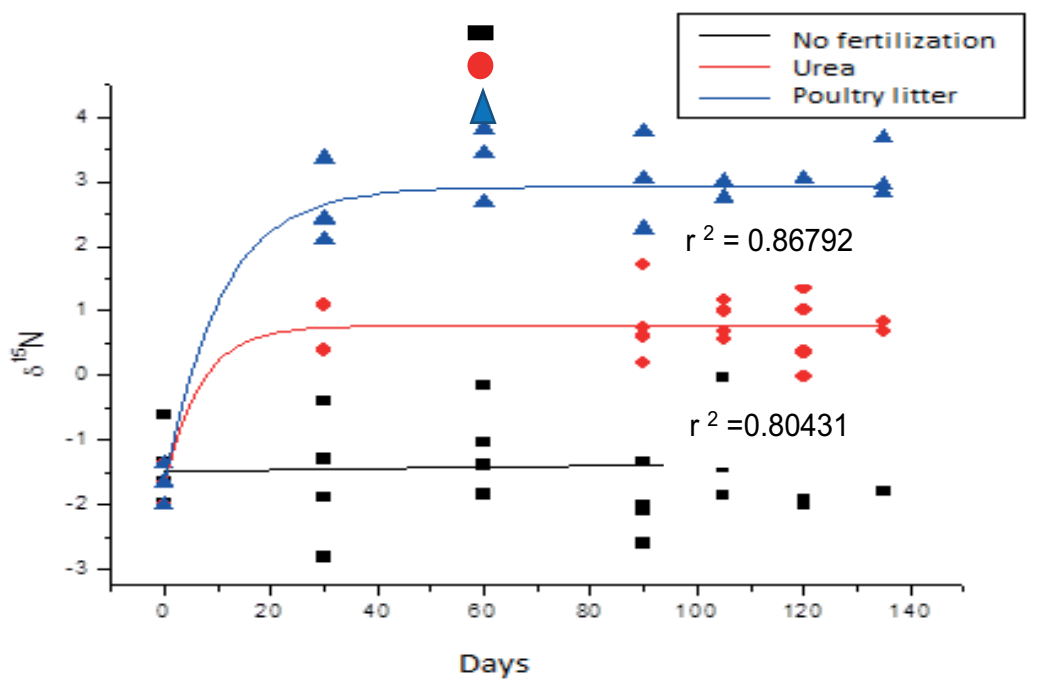

Table 7. Equation output from analysis of the results for $\delta^{15} \mathrm{~N}$, coefficients of determination $\left(\mathrm{r}^{2}\right)$ and days of incorporation along with the percentage of incorporation.

\begin{tabular}{ccccc}
\hline & Formulas & $\mathrm{r}^{2}$ & $\mathrm{~T} 1$ & $\mathrm{~T} 2$ \\
\hline Poultry litter & $\delta^{15} \mathrm{~N}=-4.59057 * \mathrm{e}^{(-0.09379 . t)}+2.92137$ & 0.86792 & 7.3 & 49.1 \\
Urea & $\delta^{15} \mathrm{~N}=-2.43466 \mathrm{e}^{(-0.14889 . t)}+0.768$ & 0.80431 & 4.7 & 30.9 \\
\hline
\end{tabular}

$\mathrm{r}^{2}=$ coefficient of determination; $\mathrm{T}=$ nitrogen half-life; $\mathrm{T} 1=50 \%$ of ${ }^{15} \mathrm{~N}$ incorporation into the pasture; $\mathrm{T} 2=99 \%$ of ${ }^{15} \mathrm{~N}$ incorporation into the pasture.

Pasture treatment with urea and poultry litter both correlated with large and significant increases in pasture dry mass, as expected with nitrogen fertilization, with no significant difference between them (Table 8). However, a strong interaction between sampling time and treatment was observed, with urea treatment promoting greater response speed and higher productivity in the first cut after fertilization. 
Table 8. Average dry matter yield ( $\mathrm{kg} / \mathrm{ha}$ ) for treatments without fertilization (SA), with urea (U) and with poultry litter $(\mathrm{CF})$ due to the cuts made.

\begin{tabular}{lcccc}
\hline Variables & \multicolumn{3}{c}{ Treatments } \\
\hline \multirow{2}{*}{ MS } & Unfertilized & Urea & \multicolumn{2}{c}{ Poultry litter } \\
\cline { 2 - 5 } Variables & $2472 \mathrm{~b}$ & $6912 \mathrm{a}$ & \multicolumn{2}{c}{$5699 \mathrm{a}$} \\
\hline & \multicolumn{3}{c}{ Collects } \\
UF & 1 & 2 & 3 & 4 \\
U & $1078 \mathrm{~b}$ & $1769 \mathrm{~b}$ & $2564 \mathrm{ab}$ & $4479 \mathrm{a}$ \\
PL & $4498 \mathrm{~b}$ & $5133 \mathrm{~b}$ & $8000 \mathrm{ab}$ & $10015 \mathrm{a}$ \\
\hline
\end{tabular}

DM: dry matter content; UC: unfertilized control; U: urea; PL: poultry litter; values with the same letter on rows are statistically similar $(\mathrm{P}>0.05) ; 1,2,3,4$ : first, second, third and fourth forage sample collections.

Corsi and Nussio (1993) reported that soil fertility and fertilization has direct effect on forage production. The more efficient use of nitrogen and responses in terms of production occur when other nutrients are in balance in the soil solution, creating a favorable environment for absorption processes by the forage plant.

We clarify that the incorporation rules alluded to in Instruction No. 25 23/07/2009 MAPA in Annex IV refers to the penetration of soil organic fertilizer applied or that this material becomes unavailable to the animal (there is no intake) and, according to our conditions climate, this occurs within 30 days of broadcast application of poultry litter (Figure 2 ). For the half-life of poultry litter, there was an estimated time of 7.3 days. As the atomic exchange of $99 \%$, the time was for 49 days. What contradicts the rules of the MAPA, which for full incorporation of fertilizer in the soil is 40 days only. For the mineral fertilizer (urea) T1 (50\%) was 4.7 days and T2 (99\%) of approximately 31 days.

The differences found between fertilizers can be explained by the respective nitrogen cycles. Urea is present in the ionic form, allowing for an easier nitrogen absorption by plants, with faster results. These processes are essential to the structure of isotopic variation in plant tissues at various spatial and temporal scales. Therefore, isotopic studies should consider these aspects of $\mathrm{N}$ isotopic biogeochemistry.

Although the isotope data that have been and continue to be generated derive mainly from tissues of animal origin, the basis for their interpretation are the biochemical processes that influence isotopic fractionation in the food chain. Considerable progress has been made in assessing the complexity of isotopic variation in plant-soil systems. However, understanding these processes in a more comprehensive manner through extensive field and laboratory studies is still in early stages.

Most studies that tried to differentiate inorganic and organic fertilized crops found that plants treated with inorganic fertilizers have significantly lower $\delta^{15} \mathrm{~N}$ values (BATEMAN et al., 2005; CHOI et al., 2006). Given the importance of inorganic fertilizers in modern agriculture, this should be taken into account when data derived from cultivated plants of modern research are used as basis for diet (KEEGAN; DENIRO, 1988; SZPAK et al., 2013; WARINNER et al., 2013).

To calculate poultry litter degradation within the "litter bags", we estimated the loss of material close to the soil during the entire experimental period. There was no overall degradation of the present fertilizer. Total degradation of poultry litter would take approximately 236 days (Figure 3). 
Figure 3. Estimated fertilizer loss during the trial period.

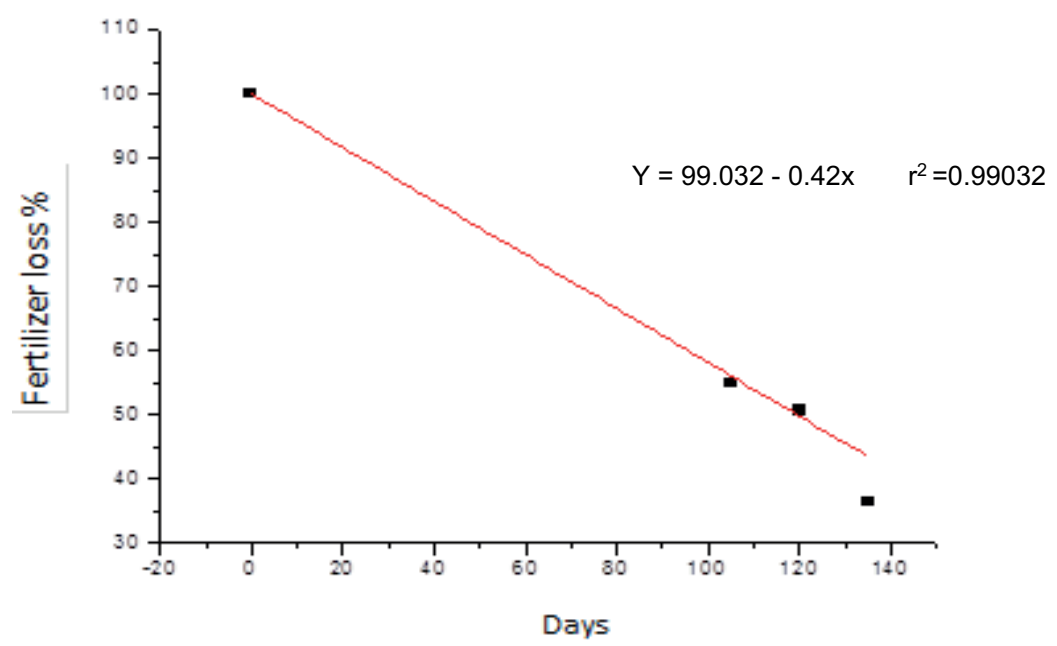

Decomposition of poultry litter depends on microbial activity and organic matter content, and is related to factors intrinsic to the material, tissue composition and environmental factors such as rainfall and temperature. Poultry litter has a higher degradation rate, leaving the ground only wood shavings which was the organic fertilizer.

The composition of nitrogen isotopes in inorganic nitrogen fertilizers has been well documented in the literature (FREYER, 1974; VITÒRIA et al., 2004). Kendall (1998) stated that synthetic nitrogen fertilizers generally have nitrogen isotope values between -4 and $4 \%$, in agreement with those found in this study (urea: $\delta^{15} \mathrm{~N}=2.09 \%$ ), except for the poultry litter $\left(\delta^{15} \mathrm{~N}\right.$ $=13.36$ ).

Soil fertility and fertilization have a direct effect on forage production. The more efficient use of $\mathrm{N}$ and responses in terms of production occur when other nutrients are balanced in the soil solution, creating a favorable environment for absorption by the forage plant (CORSI; NUSSIO, 1993). Although we did not measure the increase of nutrients in the soil (originated from the poultry litter), a contribution for $\mathrm{N}$ and other nutrients, including phosphate and potassium (also responsive to forage production), can be inferred.
Nitrogen emanated from inorganic or organic manure can be used as a useful discriminator for the fertilizer effect on the crop. Therefore, it should have priority over other factors. The aforementioned ${ }^{15} \mathrm{~N}$ fertilizer values refer to total nitrogen in these samples. The nitrogen form is known for synthetic nitrogen fertilizers. However, nitrogen fractions

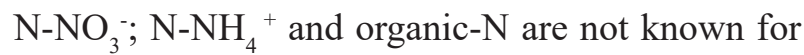
fertilizers allowed in organic systems.

Inorganic fertilizers (synthetic) are commonly applied as water-soluble $25 \mathrm{~mm}$ (diameter) granules. The release of nitrogen in an inorganic nitrogen form occurs often. Unlike the process that takes place in poultry litter, $\mathrm{N}$ becomes immediately available for the plant after the granules are dissolved. $\mathrm{N}_{-} \mathrm{NH}_{4}^{+}$ is released and nitrification of ammonium to nitrate occurs, usually before the nitrogen is absorbed by the plant.

Nitrogen transformations are accompanied by fractionation of isotopes that can affect the isotopic composition of nitrogen species. For example, after the application of synthetic urea, ammonia gas $\left(\mathrm{NH}_{3}\right)$ may be formed and some nitrogen may be lost to the atmosphere, particularly when the soil is dry. When volatilization occurs, there is preferential loss of the ammonia isotope ${ }^{14} \mathrm{NH}_{3}$, compared to ${ }^{15} \mathrm{NH}_{3}$, leaving the residual nitrogen in the soil 
enriched in ${ }^{15} \mathrm{~N}$. In contrast to inorganic fertilizers and compound fertilizers usually contain small amounts of soluble nitrogen and organic nitrogen mineralization suffering before it is available to plants, process occurred in poultry litter in this work. However, inorganic fertilizers are also susceptible to loss of nitrogen through volatilization, and as is the case with losses of ammonia after application of synthetic urea, volatilization will result in the enrichment of the remaining fraction ${ }^{15} \mathrm{~N}$.

Nitrogen cycling processes and their associated fractioning are one of the reasons why ${ }^{15} \mathrm{~N}$ values in the plant may not match the amount of nitrogen isotopes on the fertilizer applied. In addition, cultures also use pre-existing nitrogen in the soil by organic matter. Nakano et al. (2003) and Choi et al. (2003) suggest that the composition of nitrogen isotope in a crop may be a suitable discriminator organic and conventional among products grown and were based on results from tests of cultivation the cultures used inorganic nitrogen fertilizer or using a type of fertilizer which can be allowed in organic agriculture. In these experiments, other factors that can influence ${ }^{15} \mathrm{~N}$ at harvest they were kept between treatments. Other studies have shown that the fertilizer application time, soil moisture conditions, the nitrate concentration and isotopic composition of nitrate nitrogen in the irrigation water can all be influential in determining the isotopic composition of the crop nitrogen (CHOI et al., 2003).

The best evaluation being approach isotopes of nitrogen have any future as a suitable tool to discriminate between products from organic and conventional systems can be made from a survey of ${ }^{15} \mathrm{~N}$ values of authentic commercially grown crops throughout a wide geographical distribution, however as in the present study, the geographical and climatic conditions are the same, the differences in the compositions of nitrogen isotopes in the studied grass is attributed to the use of fertilizer and influence the time of sealing in comparison to the time of application of the same .

\section{Conclusions}

The technique of stable isotopes of nitrogen was effective in distinguishing the presence of inorganic and organic fertilizers in the deferred Urochloa brizantha $\mathrm{cv}$. Marandu pasture.

The source of $\mathrm{N}$ did not affect grass quality. The first time of seal is recommended to promote better quality of the deferred forage.

Differences in grass productivity can be attributed to the fertilizer and cutting seasons (seasonality) used in the experimental conditions of this study.

\section{References}

ANDRADE, C. M. S.; VALENTIM, J. F. Recuperação da produtividade de pastagem de Brachiaria brizantha cv. Marandu com adubação nitrogenada e fosfatada. In: REUNIÃO ANUAL DA SOCIEDADE BRASILEIRA DE ZOOTECNIA, 41., 2004, Campo Grande. Anais... Campo Grande: SBZ, 2004. CD-ROM.

ARRUDA, G. M. M. F. Produtividade de massa seca e proteina bruta do capim-elefante cv. Napier em função da adubação orgânica e mineral. 2012. Dissertação (Mestrado em Zootecnia) - Faculdade de Medicina Veterinária e Zootecnia. Universidade Estadual Paulista, Botucatu.

BATEMAN, A. S.; KELLY, S. D.; JICKELLS, T. D. Nitrogen isotope relationships between crops and fertilizer: implications for using nitrogen isotope analysis as an indicator of agricultural regime. Journal of Agricultural and Food Chemistry, Washington, v. 53, n. 7, p. 5760-5765, 2005.

BATISTA, K.; MONTEIRO, F. A. Respostas morfológicas e produtivas do capim-marandu adubado com doses combinadas de nitrogênio e enxofre. Revista Brasileira de Zootecnia, Viçosa, MG, v. 35, n. 4, p. 12811288, 2006.

BOCOCK, K. L.; GILBERT, O. The disappearance of leaf litter under different woodland conditions. Plant and Soil, The Hague, v. 9, p. 179-85, 1975.

CARVAlHO, T. B.; ZEN, S.; TAVARES, E. C. N. Comparação de custo de produção na atividade de pecuária de engorda nos principais países produtores de carne bovina. In: CONGRESSO DA SOCIEDADE BRASILEIRA DE ECONOMIA, ADMINISTRAÇÃO E SOCIOLOGIA RURAL, 47., 2009, Porto Alegre. Anais... Porto Alegre: SOBER, 2009. Disponível em: $<$ http:// 
www.sober.org.br/palestra/13/356.pdf > . Acesso em: 22 abr. 2016.

CHOI, W.; ARSHAD, M.; CHANG, S.; KIM, T. Grain ${ }^{15} \mathrm{~N}$ of crops applied with organic and chemical fertilizers in a four-year rotation. Plant Soil, Gwangju, v. 284, p. 165-174, 2006.

CHOI, W. J.; RO, H. M.; HOBBIE, E. A. Patterns of natural ${ }^{15} \mathrm{~N}$ in soils and plants from chemically and organically fertilized uplands. Soil Biology and Biochemistry, Oxford, v. 35, p. 1493-1500, 2003.

CORSI, M. Pastagem de alta produtividade. In: SIMPÓSIO SOBRE MANEJO DE PASTAGENS, 8., 1986, Piracicaba. Anais... Piracicaba: Fundação de Estudos Agrários Luiz de Queiroz, 1986. p. 499-512.

CORSI, M.; NUSSIO, L. G. Manejo do capim-elefante: correção e adubação do solo. In: SIMPÓSIO SOBRE MANEJO DA PASTAGEM, 10., 1993, Piracicaba. Anais... Piracicaba: Fundação de Estudos Agrários Luiz de Queiroz, 1993. p. 87-116.

DEBLITZ, C. Beef and sheep report: understanding agriculture worldwide. [S.1.]: Agri Benchmark, 2012. 22 p. Available at: <http://www.agribenchmark.org/ fileadmin/Dateiablage/B-Beef-and-Sheep/WorkingPaper/bs-05-USEU-neu.pdf $>$. Accessed at: 23 abr. 2016.

FERRAZ, J. B. S.; FELÍCIO, P. E. D. Production systems: an example from Brazil. Meat Science, Savoy, v. 84, n. 2, p. 238-243, 2010.

FREYER, H. D.; ALY, A. I. M. Nitrogen-15 variations in fertilizer nitrogen. Journal Environmental Quality, Madison, v. 3, n. 4, p. 405-407, 1974.

FRIEND, A. L.; ROBERTS, S. D.; SCHOENHOLTZ, S. H.; MOBLEY, J. A.; GERARD, P. D. Poultry litter application to Loblolly pine forests: Growth and nutrient containment. Journal Environmental Quality, Madison, v. 35, n. 3, p. 837-848, 2006.

HOBSON, K. A.; CLARK, R. G. Assessing avian diets using stable isotopes $\mathrm{I}$ : turnover of ${ }^{13} \mathrm{C}$ in tissues. The Condor, Petaluma, v. 94, n. 1, p. 181-188, 1992.

INSTITUTO BRASILEIRO DE GEOGRAFIA E ESTATÍSTICA - IBGE. Censo agropecuário 1920/2006: até 1996, dados extraídos de Estatística do Século XX. Rio de Janeiro, 2007. Disponível em: $<$ http://seriesestatisticas. ibge.gov.br/series.aspx? vcodigo $=$ AGRO02 $>$. Acesso em: 22 abr. 2016.

KEEGAN, W. F.; DENIRO, M. J. Stable carbon- and nitrogen-isotope ratios of bone collagen used to study coral-reef and terrestrial components of prehistoric Bahamian diet. American. Antiquity, Washington, v. 53, n. 2, p. 320-336, 1988.
KENDALL, C. Tracing nitrogen sources and cycles in catchments. In: KENDALL, C.; McDONNELL, J. J. (Ed.). Isotope tracers in catchment hydrology. Amsterdam: Elsevier, 1998. p. 534-569.

LOMBARDI NETO, F.; DRUGOWICH, M. I. Manual técnico de manejo e conservação de solo e água. Campinas: CATI, 1994. v. 2, 168 p.

MARTHA JÚNIOR, G. B.; VILELA, L.; BARIONI, L. G. SOUSA, D. M. G. de; BARCELlOS, A. O. Manejo da adubação nitrogenada em pastagens. In: SIMPÓSIO SOBRE MANEJO DA PASTAGEM, 21., 2004, Piracicaba. Anais... Piracicaba: Fundação de Estudos Agrários Luiz de Queiroz, 2004. p. 155-216.

McGRATH, S.; MAGUIRE, R. O.; TACY, B. F.; KIKE, J. H. Improving soil nutrition with poultry litter application in low input forage systems. Agronomy Journal, Blacksburg, Virginia, v. 102, n. 1, p. 48-54, 2009.

MENEZES, J. F. S.; ALVARENGA, R. C.; SILVA, G. P.; KONZEN, E. A.; PIMENTA, F. F. Cama de frango na agricultura: perspectivas e viabilidade técnica e econômica. Rio Verde: FESURV, 2004. 28 p. (Boletim técnico, 3).

MERTENS, D. R. Gravimetric determination of amylasetreated neutral detergent fiber in feeds with refluxing in beakers or crucibles: collaborative study. Journal of AOAC International, Madison, v. 85, n. 6, p. 1217-1240, 2002.

MINITAB 16 Statistical Software. Computer software. [S.1.]: Minitab Inc., 2010.

MINISTÉRIO DA AGRICULTURA, PECUÁRIA E ABASTECIMENTO - MAPA. Instrução Normativa $n^{\circ}$. 8 , de 25 de março de 2004. Proíbe em todo o território nacional a produção, a comercialização e a utilização de produtos destinados à alimentação de ruminantes que contenham em sua composição proteínas e gorduras de origem animal. Diário Oficial [da] União, Brasília, DF, 26 mar. 2004, Seção 1, p. 5.

Instrução Normativa $\mathrm{n}^{\circ} .15$, de 26 de maio de 2009. Regulamentar o registro dos estabelecimentos e dos produtos destinados à alimentação animal. Diário Oficial [da] União, Brasília, DF, 28 maio 2009, Seção 1, p. 1-8.

Secretaria de Defesa Agropecuária. Instrução normativa ${ }^{\circ} 25$, de 27 de Julho de 2009. Diário Oficial [da] União, Brasília, DF, 27 jul. 2009. Seção 1, p. 8.

NAKANO, A.; UEHARA, Y.; YAMAUCHI, A. Effect of organic and inorganic fertigation on yields, $\delta^{15} \mathrm{~N}$ values, and $\delta^{15} \mathrm{~N}$ values of tomato (Lycopersicon esculentum Mill. cv. Saturn). Plant Soil, The Hague, v. 255, p. 343349,2003 . 
NYAKATAWA, E. Z.; REDDY, K. C.; BROWN, G. F. Residual effect of poultry litter applied to cotton in conservation tillage systems on succeeding rye and corn. Field Crops Research, Alabama, v. 71, n. 3, p. 159-171, 2001

ASSOCIATION OF OFFICIAL ANALYTICAL CHEMISTS - AOAC. Official methods of analysis. 16. ed. Arlington: AOAC International, 1995. 2v.

PAUL, E. A.; CLARK, F. E. Soil microbiology and biochemistry. San Diego: Academic Press, 1996. 340 p.

PREUSCH, P. L.; ADLER, P. R.; SIKORA, L. J.; TWORKOSKI, T. J. Nitrogen and phosphate availability in composted and uncomposted poultry litter. Journal of Environmental Quality, Madson, v. 31, n. 6, p. 20512057, 2002.

SCHAEFFER, E.; CAUGANT, M. Traçabilité guide pratique pour l'agriculture e l'industrie alimentaire. ACTA-ACTIA. Guide pratique pour l'agriculture et l'industrie agroalimentaire. Paris: ACTA-ACTIA, 1998. $80 \mathrm{p}$.
SZPAK, P.; WHITE, C. D.; LONGSTAFFE, F. J.; MILLAIRE, J-F.; VA'SQUEZ SA'NCHEZ, V. F. Carbon and nitrogen isotopic survey of northern peruvian plants: baselines for paleodietary and paleoecological studies. PLoS ONE, v. 8, n. 1, e53763, 2013.

VAN SOEST, P. J.; ROBERTSON, J. B.; LEWIS, B. A. Symposium: carbohydrate methodology, metabolism, and nutritional implications in dairy cattle. Methods for dietary fiber, neutral detergent fiber, and nonstarch polysaccharides in relation to animal nutrition. Journal of Animal Science, Champaign, v. 74, p. 3583-3597, 1991.

VITÒRIA, L. N.; OTERO, A.; SOLER, A.; CANALS, A. Fertilizer characterization: isotopic data $(\mathrm{N}, \mathrm{S}, \mathrm{O}, \mathrm{C}$, and Sr). Environmental Science \& Technology, Barcelona, v. 38, n. 12, p. 3254-3262, 2004.

WARINNER, C.; GARCIA, N. R.; TUROSS, N. Maize, beans and the floral isotopic diversity of highland Oaxaca, Mexico. Journal of Archaeological Science, Cambridge, v. 40, n. 2, p. 868-873, 2013. 